\title{
PENERAPAN MODEL PEMBELAJARAN COOPERATIVE LEARNING TIPE ROLE $P L A Y$ UNTUK MENINGKATKAN KEAKTIFAN DAN KEMAMPUAN SPEAKING MAHASISWA SEMESTER 1 PROGRAM STUDI PENDIDIKAN BAHASA INGGRIS FKIP-UNIVERSITAS GUNUNG RINJANI
}

\author{
Zaenul Fikri ${ }^{1}$, Sulaiman ${ }^{2}$, Ahmad Busyairi ${ }^{3}$ \\ 1,2,3 Fakultas Keguruan dan Ilmu Pendidikan - Universitas Gunung Rinjani \\ fikrizaenul@gmail.com \\ hatiku.entebe@gmail.com \\ alfaatihnamaku@gmail.com
}

\begin{abstract}
Abstrak
Berdasarkan hasil observasi yang dilakukan oleh peneliti pada mahasiswa semester 1 Prodi. Pendidikan Bahasa Inggris FKIP-UGR pada tanggal 15 September 2021 didapatkan bahwa permasalahan utama pada mahasiswa adalah kurangnya keaktifan mahasiswa pada proses pembelajaran yang ditandai dengan rendahnya kemampuan bertanya, menjawab, berdiskusi, dan bekerjama sama dengan mahasiswa lainnya. Selain itu permasalahan mahasiswa pada mata kuliah Intensive Listening and Speaking adalah masih rendahnya kemampuan keterampilan Speaking mahasiswa. Hal ini sejalan dengan apa yang ditemukan oleh peneliti di sekolah yang dijadikan mitra dalam program kemitraan dosen dengan sekolah yakni masih kurangnya keaktifan siswa dalam proses pembelajaran dan rendahnya kemampuan speaking siswa diantara keemapat skill yang ada dalam mata pelajaran Bahasa Inggris. Dari permasalahan di atas diperlukan sebuah strategi yang dapat meningkatkan keaktifan dan kemampuan speaking mahasiswa pada mata kuliah Intensive Listening and Speaking yakni penerapan model cooperative learning dengan teknik role play. Sehingga tujuan dari penelitian ini adalah untuk meningkatkan keaktifan dan kemampuan speakingmahasiswasemester 1 Prodi. Pendidikan Bahasa Inggris FKIP-UGR.
\end{abstract}

Kata kunci: Cooperative Learning, Role Play, Keaktifan Belajar, Speaking

\section{Abstract}

Based on the results of observations made by researchers on semester 1 students of Study Program. FKIPUGR English Education on September 15, 2021, it was found that the main problem for students is the lack of student activity in the learning process which is characterized by low ability to ask questions, answer, discuss, and collaborate with other students. In addition, the problem of students in the Intensive Listening and Speaking course is that students' speaking skills are still low. This is in line with what was found by researchers at schools that are partners in the lecturer partnership program with schools, namely the lack of student activity in the learning process and the low speaking ability of students among the four skills in English subjects. From the problems above, a strategy is needed that can increase the activeness and speaking ability of students in the Intensive Listening and Speaking course, namely the application of cooperative learning models with role play techniques. So the purpose of this research is to increase the activeness and speaking ability of semester 1 students of study program. English Education FKIP-UGR.

Keywords: Cooperative Learning, Role Play, Active Learning, Speaking 


\section{PENDAHULUAN}

Universitas Gunung Rinjani (UGR) merupakan salah satu perguruan tinggi swasta yang ada di Provinsi Nusa Tenggara Barat (NTB) lebih tepatnya di Kabupaten Lombok Timur. UGR itu sendiri memiliki salah satu Fakultas Keguruan dan Ilmu Pendidikan yang salah satu di dalamnya adalah Program Studi Pendidikan Bahasa Inggris. Sebagai perguruan tinggi swasta tentunya tidak memiliki kwalitas yang mumpuni apabila dibandingkan dengan pergurun-perguruan tinggi negeri lainya yang ada di provinsi NTB yang dipengaruhi oleh beberapa factor salah satunya adalah intake mahasiswa.

Berdasarkan hasil observasi yang dilakukan oleh peneliti pada mahasiswa semester 1 Prodi. Pendidikan Bahasa Inggris FKIP-UGR pada tanggal 15 September 2021 didapatkan bahwa permasalahan utama pada mahasiswa adalah kurangnya keaktifan mahasiswa pada proses pembelajaran yang ditandai dengan rendahnya kemampuan bertanya, menjawab, berdiskusi, dan bekerjama sama dengan mahasiswa lainnya. Selain itu permasalahan mahasiswa pada mata kuliah Intensive Listening and Speaking adalah masih rendahnya kemampuan keterampilan Speaking mahasiswa. Hal ini sejalan dengan apa yang ditemukan oleh peneliti di sekolah yang dijadikan mitra dalam program kemitraan dosen dengan sekolah yakni masih kurangnya keaktifan siswa dalam proses pembelajaran dan rendahnya kemampuan speaking siswa diantara keempat skill yang ada dalam mata pelajaran Bahasa Inggris.

Dari kedua permasalahan di atas yang terdapat pada mahasiswa semester 1 Prodi Pendidikan Bahasa Inggris FKIP-UGR dan siswa SMA Negeri 1 Wanasaba yakni terkait dengan keaktifan siswa dan masih rendahnya kemampuan Speaking siswa dijadikan dasar oleh penelitian untuk mengatasi permasalahan yang dihadapi oleh mahasiswa semester 1 Prodi Pendidikan Bahasa Inggris FKIP-UGR melalui model pembelajaran Cooperative Learning dengan salah satu tekniknya yakni Role Play yang berbasis Penelitian Tindakan Kelas (PTK).

Fasilitas yang dimiliki oleh sekolah atau kampus bukan merupakan faktor utama yang menentukan efektifnya pembelajaran yang dilakukan oleh guru/dosen akan tetapi ada faktor-faktor lain yang menentukan keefektifan pembelajaran di kelas seperti kemampuan guru/dosen di dalam mengimplementasikan model - model pembelajaran di kelas dan kemampuan memanfaatkan dan mengoptimalkan sumbersumber belajar di sekitar lingkungan sekolah atau kampus (Yulianto, 2016).

Hal di atas senada dengan apa yang dimanahkan dalam undang-undang Republik Indonesia nomor 14 tahun 2005 bahwa salah satu kompetensi yang wajib dimiliki oleh guru adalah kompetensi professional. Utamami \& Hasanah (2020) menjelaskan bahwa kompetensi professional merupakan salah satu kompetensi yang berkaitan dengan kemampuan merencanakan, melaksanakan sampai kepada mengevaluasi pembelajaran. Selanjutnya Hamdi (2019) mengungkapakan bahwa salah satu faktor yang menentukan kualitas pembelajaran itu sendiri adalah guru atau dosen sehingga dosen sangat memainkan peran yang sangat penting dalam menentukan kualitas pembelajaran yang berimplikasi kepada meningkatnya kualitas pendidikan.

Model Cooperative Learning merupakan solusi yang ditawarkan kepada mahasiswa semester 1 Prodi Pendidikan Bahasa Inggris FKIP-UGR dalam upaya meningkatkan keaktifan mahasiswa di kelas dan teknik Role Play yang juga merupakan salah satu tipe model cooperative learning diyakini mampu meningkatkan rendahnya 
kemampuan speaking mahasiswa pada mata kuliah Intensive Listening \& Speaking.

Slavin (dalam Nurdyansyah \& Fahyuni, 2016) menjelaskan bahwa model cooperatiave learning dapat mendorong siswa berinteraksi secara aktif dan positif dalam kelompok, terciptanya pertukaran ide antar siswa dalam suasana yang nyaman berdasarkan falsafah konstruktivisme.

Selanjutnya Slavin (dalam Nurdyansyah \& Fahyuni, 2016) menjelaskan kelebihan dari cooperative learning itu sendiri bahwa: (1) cooperative learning dapat meningkatkan prestasi belajar siswa dan sekaligus dapat meningkatkan hubungan sosial, menumbuhkan sikap toleransi, dan menghargai pendapat orang lain, (2) cooperative learning dapat memenuhi kebutuhan siswa dalam berpikir kritis, memecahkan masalah, dan mengintegrasikan pengetahuan dengan pengalaman.

Role play merupakan salah satu teknik pada model cooperative learning diyakini dapat meningkatkan kemampuan speaking siswa. Brown (2004) mengungkapakan bahwa role play merupakan aktifitas pedagogis dalam pembelajaran Bahasa yang komunikatif dimana dapat membuat siswa bebas menjadi orang lain berdasarkan kreatifitas Bahasa mereka. Hal ini sejalan dengan apa yang dijelaskan oleh Nunan (1989) bahwa teknik role play itu sangat penting dalam pengajaran speaking karena dapat memberikan kesempatan kepada siswa untuk praktik berkomunikasi dengan konteks sosial yang berbeda dan dengan Bahasa yang sedang dipelajari.

Berdasarkan permasalahan yang dihadapi oleh mahasiswa semester 1 Prodi. Pendidikan Bahasa Inggris FKIP-Universitas Gunung Rinjani, yakni rendahnya keaktifan mahasiswa di kelas dan kurangnya kemampuan speaking mahasiswa pada mata kuliah Intensive Listening and Speaking, model pembelajaran cooperative learning dengan tipe role play diyakini mampu meningkatkan keaktifan belajar mahasiswa di kelas dan mampu meningkatkan kemampuan speaking mahasiswa pada mata kuliah Intensive Listening and Speaking. Sehingga penelitian ini bertujuan untuk mengetahui apakah model cooperative learning dengan tipe role play dapat meningkatkan keaktifan belajar mahasiswa semester 1 Pordi. Pendidikan Bahasa inggris FKIP-UGR dan dapat meningkatkan kemampuan speaking mahasiswa.

\section{METODE PENELITIAN}

Penelitian ini merupakan Penelitian Tindakan Kelas (Classroom Action Research). Pada kegiatan PTK ini peneliti ingin memberikan tindakan sesuai apa adanya tanpa terlibat dalam proses pembelajaran dengan tujuan untuk mencari solusi dalam masalah pembelajaran di kelas. Penelitian ini berlokasi di Universitas Gunung Rinjani Kabupaten Lombok Timur Nusa Tenggara Barat. Penelitian ini dilaksanakan selama 2 bulan pada semester ganjil mulai dari bulan Oktober sampai dengan November 2021. Subjek Penelitian ini adalah mahasiswa semester 1 Prodi. Pendidikan Bahasa Inggris FKIP-Universitas Gunung Rinjani sebanyak 31 mahasiswa. Penelitian ini menggunakan model cooperative learning tipe role play untuk meningkatkan keaktifan mahsiswa dan kemampuan speaking mahasiswa pada mata kuliah Intensive Listening \& Speaking. Ada beberapa istrumen dalam penelitian ini antara lain: a) Lembar observasi keaktifan siswa. b) Lembar penilaian Speaking. Data dalam penelitian ini diperoleh dari: 1) keaktifan mahasiswa di kelas seperti keaktifan berdiskusi, bekerjasama, bertanya, menjawab pertanyaan, dan performance di depan kelas, dan 2) Lembar penilaian kemampuan Speaking. Pengumpulan data dalam penelitian ini melalui: 1) keaktifan siswa di kelas seperti keaktifan berdiskusi, 
Vol. 10. No. 1. Tahun 2022

bekerjasama, bertanya, menjawab pertanyaan, dan performance di depan kelas, dan 2) Lembar penilaian kemampuan Speaking.

\section{Teknik Analisis Data}

Ada beberapa teknik analisis data yang digunakan dalam penelitian ini adalah sebagai berikut:

1. Analisis Data Keaktifan Belajar Mahasiswa.

Data keaktifan belajar mahasiswa dianalisis dengan menggunakan rumus berikut:

$\%$ Keaktifan belajar siswa =

Sskor keaktifan belajar siswa yang diperoleh $\overline{\sum \text { skor maksimum keaktifan belajar siswa tiap indika }}$

Kesimpulan analisis data disesuaikan dengan persentase keaktifan mahasiswa sebagai berikut:

\begin{tabular}{|l|l|}
\hline \multicolumn{1}{|c|}{ Persentase } & \multicolumn{1}{c|}{ Kriteria } \\
\hline $81-100$ & Sangat Baik \\
\hline $61-80$ & Baik \\
\hline $41-60$ & Cukup \\
\hline $21-40$ & Kurang \\
\hline
\end{tabular}

\begin{tabular}{|l|l|}
\hline $0-20$ & Sangat Kurang \\
\hline Sumber: Adaptasi Arikunto, (2006)
\end{tabular}

2. Analisis skor Speaking mahasiswa Untuk melihat peningkatan skor kemampuan speaking mahasiswa pada masing-masing siklus digunakan rumus sebagai berikut:

$$
\bar{X}=\frac{\sum x}{n}
$$

$\bar{X}=$ Nilai Rata - Rata

$x=$ Total Skor

$n=$ Jumlah Mahasiswa

selanjutnya dianalisis persentase jumlah mahasiswa yang lulus dengan rumus sebagai berikut:

$$
\begin{aligned}
& P=\frac{F}{N} \times 100 \% \\
& P=\text { Persentase } \\
& F=\text { Total Persentase } \\
& N=\text { Jumlah Siswa }
\end{aligned}
$$

\section{HASIL DAN PEMBAHASAN}

\section{A. Hasil}

\section{Pra Siklus}

a. Keaktifan Belajar Mahasiswa

Berikut adalah gambaran atau data keaktifan belajaran mahasiswa dan presentase keaktifan belajar mahasiswa pada pra siklus:

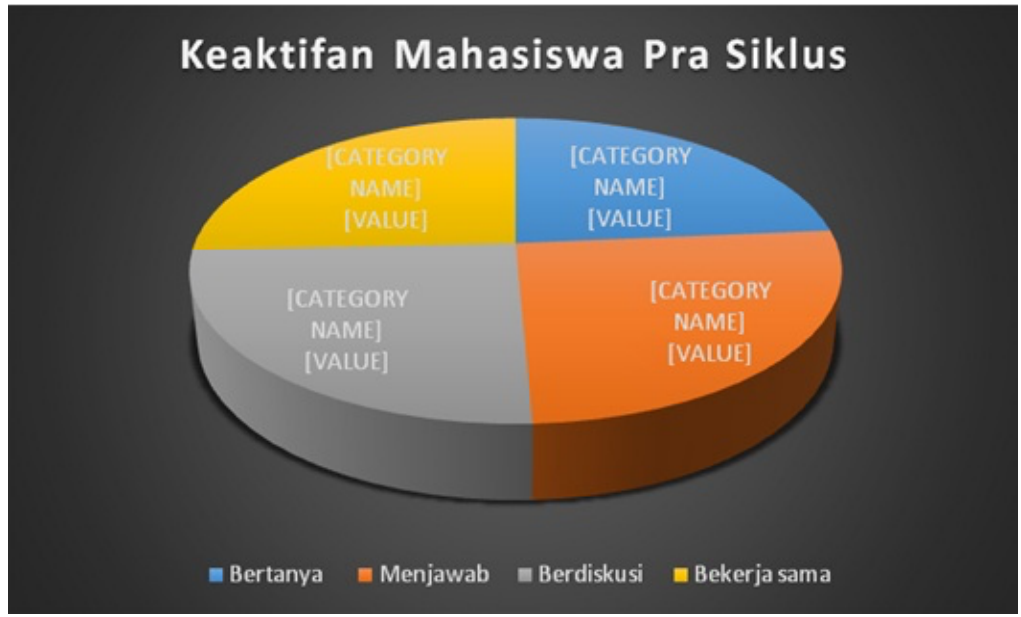

Gamber 4.1 Diagram Keaktifan Belajar Mahasiswa Pra Siklus 
Vol. 10. No. 1. Tahun 2022

Dari Chart 4.1 diatas yang diperoleh melalui porses observasi pada pra siklus tergambar bahwa siswa yang aktif bertanya (34\%), menjawab (37\%), berdiskusi (36\%), dan bekerja sama $(37 \%)$.

b. Pre Test

Sebagai bagian dari observasi untuk mendapatkan gambaran awal tentang kemampuan speaking mahasiswa, peneliti memberikan pre-test dalam bentuk oral test. Nilai ratarata kemampuan speakingmahasiswa adalah enam puluh lima (65). Berikut adalah rekapitulasi nilai pre test mahasiswa semester 1 Prodi. Pendidikan Bahasa Inggris FKIP-UGR:

\begin{tabular}{|c|l|c|c|c|}
\hline No & \multicolumn{1}{|c|}{ Range Nilai } & $\begin{array}{c}\text { Jumlah } \\
\text { Mahaiswa }\end{array}$ & Persentase & Nilai Akhir \\
\hline 1. & $0-55$ & 6 & 0,19 & E \\
\hline 2. & $56-64$ & 11 & 0,36 & D \\
\hline 3. & $65-74$ & 8 & 0,26 & C \\
\hline 4. & $75-84$ & 4 & 0,13 & B \\
\hline 5. & $85-100$ & 2 & 0,06 & A \\
\hline 6. & Total & 31 & & \\
\hline
\end{tabular}

Table 4.1 Rekapitulasi Nilai Pre-test

Adapun data pada table diatas dapat digambarkan dalam bentuk grafik di bawah ini:

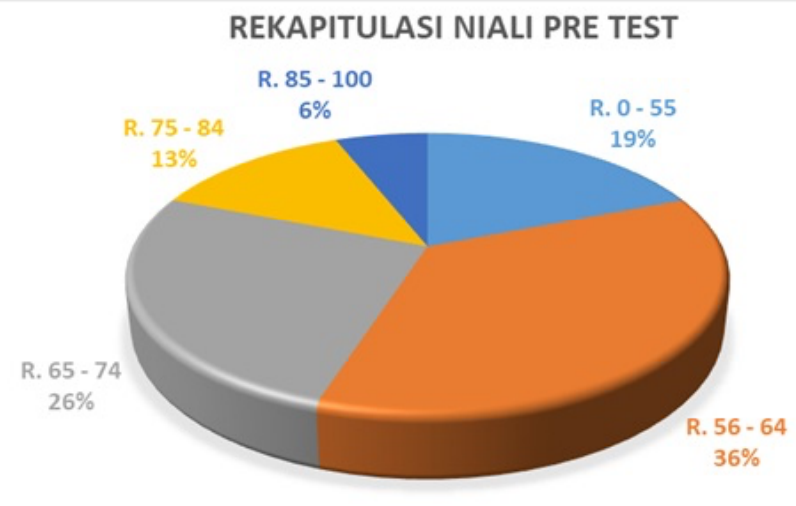

Gambar 4.2 Rekapitulasi Nilai Pre Test

Dari grafik diatas diketahui bahwa nilai pre test 31 mahasiswa prodi. Pendidikan Bahasa inggris FKIP-UGR adala mahasiswa yang memperoleh nilai 75 keatas sebesar $37 \%$ dan mahasiswa yang memperoleh nilai 75 kebawah sebesar 63\%. Selain itu, mahasiswa yang memperoleh nilai 64 kebawah sebesar 55\% yang terkategori D atau E (Tidak Lulus). Mahasiswa yang memperoleh nilai Range 65 - 74 yang terkategori $\mathrm{C}$ sebesar $26 \%$ dan hanya $6 \%$ mahasiswa yang memperoleh nilai range delapan puluh lima (85) ke atas terkategori A.

2. Keterlaksanaan Tindakan Siklus 1

a. Keaktifan Belajar Mahasiswa

Berikut adalah presentase keaktifan belajar mahasiswa pada siklus I yang dapat dilihat pada diagram 4.3 . 


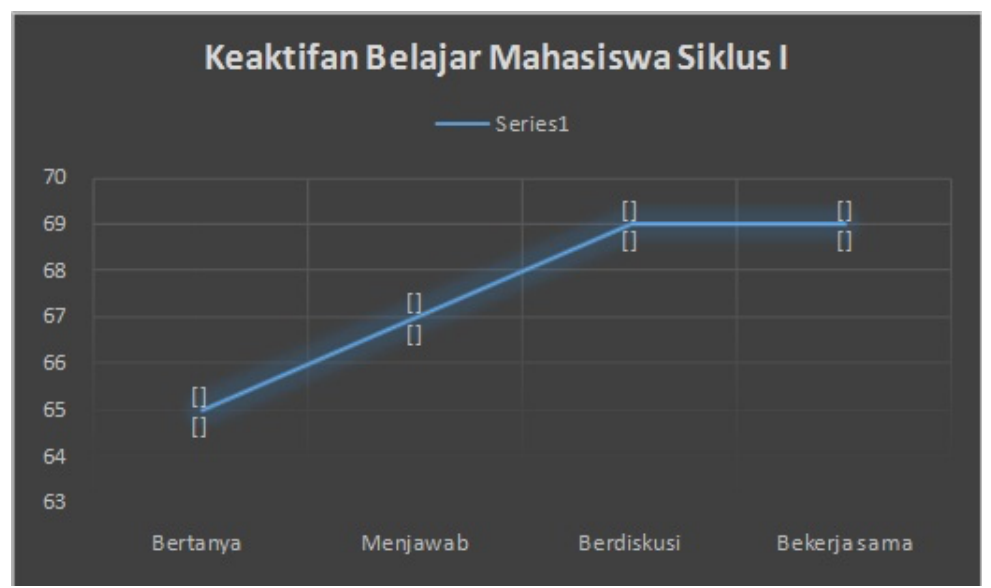

Gamber 4.3 Diagram Keaktifan Belajar Mahasiswa Siklus I

Dari Chart 4 diatas yang diperoleh melalui porses observasi pada siklus I adalah mahasiswa yang aktif bertanya (65\%), menjawab (67\%), berdiskusi (69\%), dan bekerja sama $(69 \%)$.

b. Nilai Kemampuan Speaking Mahasiswa

Setelah dilakukan pre test untuk mendapatkan gambaran nilai awal mahasiswa dilakuka proses pembelajaran dengan menggunakan model cooperative learning tipe role play dua kali pertemuan pada siklus I ini. Setelah itu dilakukan post test. Nilai rata-rata mahasiswa pada siklus 1 adalah 72,77 . Berikut adalah rekapitulasi nilai speaking mahasiswa:

\begin{tabular}{|c|l|c|c|c|}
\hline No & \multicolumn{1}{|c|}{ Range Nilai } & $\begin{array}{c}\text { Jumlah } \\
\text { Mahaiswa }\end{array}$ & Persentase & Nilai Akhir \\
\hline 1. & $0-55$ & 4 & 0,13 & E \\
\hline 2. & $56-64$ & 6 & 0,19 & D \\
\hline 3. & $65-74$ & 6 & 0,19 & C \\
\hline 4. & $75-84$ & 10 & 0,33 & B \\
\hline 5. & $85-100$ & 5 & 0,16 & A \\
\hline 6. & Total & 31 & & \\
\hline
\end{tabular}

Table 4.2 Rekapitulasi Nilai Post-test Siklus I

Data pada table diatas dapat digambarkan dalam bentuk grafik di bawah ini:

\section{REKAPITULASI NILAI POST TEST SIKLUS I}

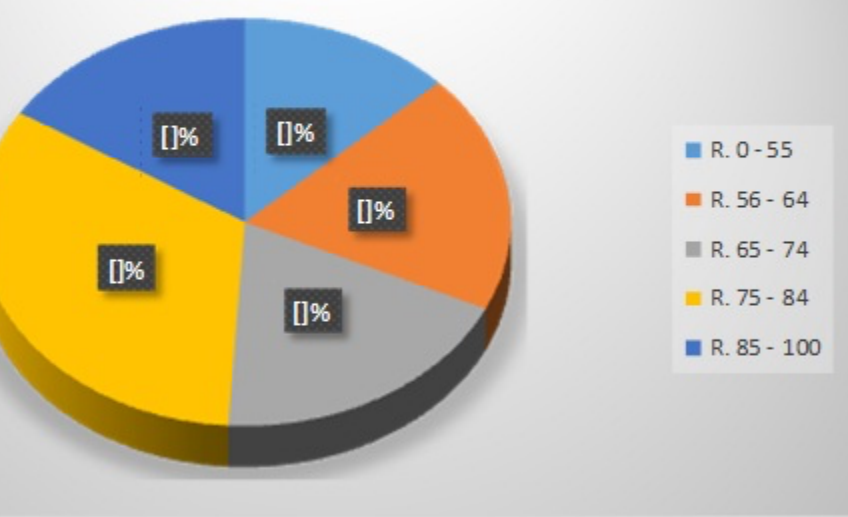

Gambar 4.4 Rekapitulasi Nilai Post Test Siklus I 
Dari grafik diatas diketahui bahwa ada peningkatan nilai post-test siklus I kalau dibandingkan dengan nilai pada pre-test sebelumnya bahwa mahasiswa yang memperoleh nilai 75 keatas sebesar $49 \%$ dan mahasiswa yang memperoleh nilai 75 kebawah sebesar 51\%. Selain itu, mahasiswa yang memperoleh nilai 64 kebawah sebesar 32\% yang terkategori D atau E (Tidak Lulus). Mahasiswa yang memperoleh nilai Range 65 - 74 yang terkategori C sebesar 19\% dan 16\% mahasiswa yang memperoleh nilai range delapan puluh lima (85) ke atas terkategori A.

3. Keterlaksanaan Tindakan Siklus II

a. Keaktifan Belajar Mahasiswa

Berikut adalah presentase keaktifan belajar mahasiswa pada siklus II yang dapat dilihat pada diagram 4.5 .

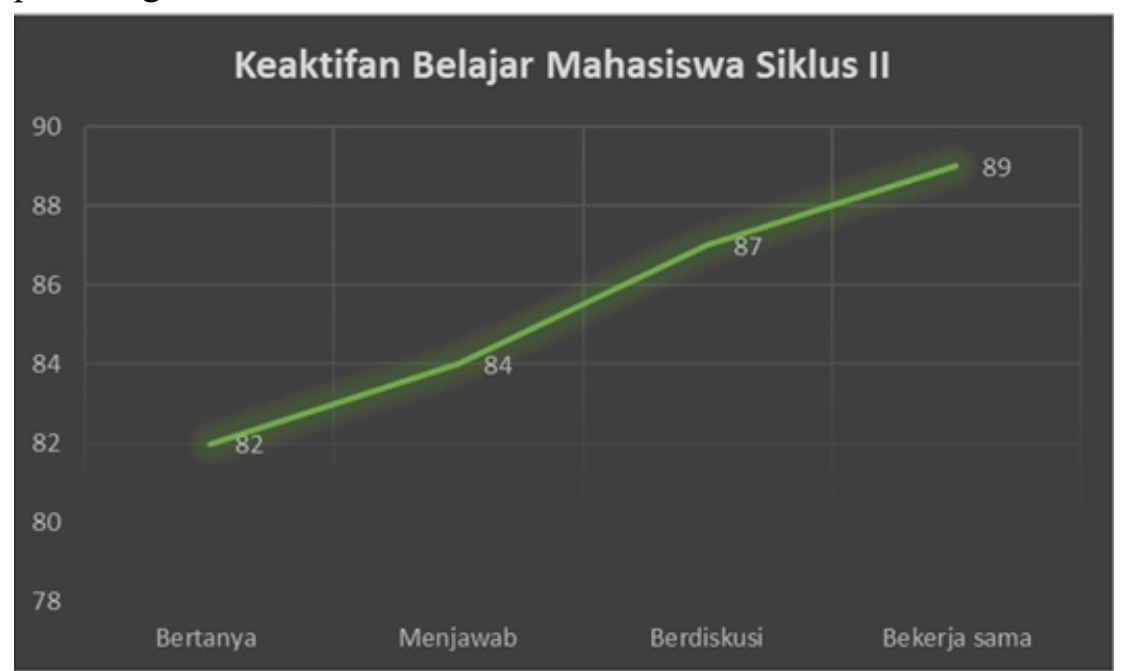

Gamber 4.5 Diagram Keaktifan Belajar Mahasiswa Siklus II

Dari Chart 4.5 diatas yang diperoleh melalui porses observasi pada siklus I adalah mahasiswa yang aktif bertanya (82\%), menjawab (84\%), berdiskusi $(87 \%)$, dan bekerja sama $(89 \%)$.

b. Nilai Kemampuan Speaking Mahasiswa

Pada siklus II ini diperoleh nilai rata-rata speaking mahasiswa adalah 80,96.Berikut adalahrekap nilai post-test kemampuan speaking mahasiswa:

\begin{tabular}{|c|l|c|c|c|}
\hline No & \multicolumn{1}{|c|}{ Range Nilai } & $\begin{array}{c}\text { Jumlah } \\
\text { Mahaiswa }\end{array}$ & Persentase & Nilai Akhir \\
\hline 1. & $0-55$ & 0 & 0,00 & E \\
\hline 2. & $56-64$ & 1 & 0,03 & D \\
\hline 3. & $65-74$ & 4 & 0,13 & C \\
\hline 4. & $75-84$ & 15 & 0,48 & B \\
\hline 5. & $85-100$ & 11 & 0,36 & A \\
\hline 6. & Total & 31 & & \\
\hline
\end{tabular}

Table 4.3 Rekapitulasi Nilai Post-test Siklus II

Dari grafik diatas diketahui bahwa ada peningkatan nilai post-test siklus II kalau dibandingkan dengan nilai pada post-test siklus I bahwa mahasiswa yang memperoleh nilai 75 keatas sebesar $84 \%$ dan mahasiswa yang memperoleh nilai 75 kebawah sebesar 16\%. Mahasiswa yang memperoleh Nilai range 75-84 sebesar $48 \%$ terkategori B. Mahasiswa yang memperoleh range 85 ke atas sebesar $36 \%$ terkategori A. 
Mahasiswa yang memperoleh nilai 64 ke bawah sebesar 3\% tekategori D atau E (Tidak Lulus).

\section{B. Pembahasan}

\section{Keaktifan Belajar Mahasiswa}

Berdasarkan hasil observasi terkait keaktifan belajar mahasiswa bahwa ada peningkatan mulai dari pra siklus, siklus I, dan siklus II. Berikut adalah diagram keaktifan belajar mahasiswa:

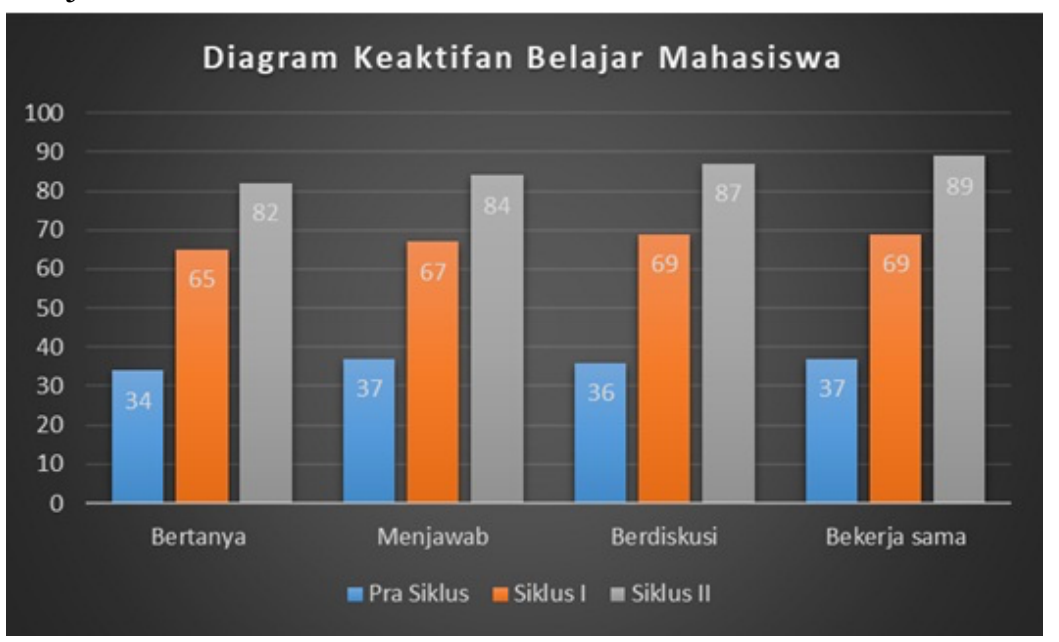

Gamber 4.6 Diagram Keaktifan Belajar Mahasiswa Per Indikator.

Dari data diatas terlihat bahwa peningkatan keaktifan belajar mahasiswa dari pra siklus ke siklus I adalah keaktifan bertanya sebesar 31\%, menjawab 30\%, berdiskusi $33 \%$, dan bekerja sama $32 \%$. Sedangakan keaktifan belajar dari siklus I ke siklus II adalah keaktifan bertanya sebesar $17 \%$, menjawab $17 \%$, berdiskusi $17 \%$, dan bekerja sama $20 \%$. Hal ini menunjukkan bahwa ada peningkatan keaktifan belajar mahasiswa pada setiap siklusnya.

\section{Peningkatan Kemampuan SpeakingMahasiswa}

Berdasarkan hasil observasi atau penilaian terkait dengan peningkatan kemampuan speakingmahasiswa mulai dari pre-test, post test siklus I, dan post test siklus II diperoleh nilai rata-rata mahasiswa pada tiap-tiap siklus sebagai berikut:

\begin{tabular}{|c|l|c|}
\hline No & \multicolumn{1}{|c|}{ Test/Siklus } & Nilai Rata-Rata \\
\hline 1. & Pre-Test (Pra Siklus) & 65 \\
\hline 2. & Post Test (Siklus I) & 72,77 \\
\hline 3. & Post Test (Siklus II) & 80,96 \\
\hline
\end{tabular}

Table 4.4 Nilai Rata-Rata Speaking Mahsiswa Per siklus

Berdasarkan table 4..diatas dijelaskan bahwa ada peningkatan kemampuan speaking mahasiswa pada tiap-tiap siklus. Pada pre-test untuk pra siklus diperoleh nilai rata-rata mahasiswa sebesar 65. Pada post test untuk siklus I diperoleh nilai rata-rata mahasiswa sebesar 72,77. Pada post test untuk siklus II diperoleh nilai rata-rata mahasiswa sebesar 80,96. Hal ini menunjukkan bahwa model cooperative learning 
tipe role play dapat meningkatkan kemampuan speaking mahasiswa semester 1 Prodi. Pendidikan Bahasa Inggris FKIP-Universitas Gunung Rinjani.

\section{KESIMPULAN}

Berdasarkan penjelasan diatas yang didukung dengan data-data dapat disimpulkan penelitian ini sebagai berikut:

1. Terkait masalah keaktifan belajar mahasiswa bahwa ada peningkatan keaktifan belajar mahasiswa pada tiap-tiap siklus yang mengindikasikan bahwa model cooperative learning dapat meningkatkan keaktifan belajar mahasiswa semester 1 Prodi. Pendidikan Bahasa Inggris FKIPUniversitas Gunung Rinjani.

2. Terkait masalah kemapuan speaking mahasiswa bahwa ada peningkatan kemapuan speaking mahasiswa pada tiaptiap siklus yang mengindikasikan juga bahwa tehnik role play dapat meningkatkan kemampua speaking mahasiswa semester 1 Prodi. Pendidikan Bahasa Inggris FKIP-Universitas Gunung Rinjani.

\section{DAFTAR PUSTAKA}

Arikunto, Suharsimi.2006. Metodologi Penelitian. Yogyakarta: Bina Aksara

Brown, H. D. 2004. Teaching by Principles: an Interactive Approach to Language Pedagogy. New York: Addison Wesley Longman.Inc.

Hamdi, Muhammad Mustafid, 2019. Konsep Pembelajaran Guru Yang Bermutu.INTIZAM: Jurnal Manajemen Pendidikan Islam. Volume 3, Nomor 1, Oktober 2019. ISSN: 2622-6161 (Online) 2598-8514 (Print)

Melati, H.A, Junanto Tulus, Lestari Ira. Lesson Study untuk Meningkatkan Kualitas pembelajaran English For Chemistry I. 2014. Diunduh dari http://download.garuda.ristekdikti.go.i d/article.php?article $=375767 \&$ val $=77$ 23\&title=LESSON $\% 20$ STUDY $\% 20 \mathrm{U}$ NTUK $\% 20$ MENINGKATKAN\%20K UALITAS $\% 20$ PEMBELAJARAN\% 2 0ENGLISH $\% 20 \mathrm{FOR} \% 20 \mathrm{CHEMISTR}$ Y\%20I

Nunan, D. 1989. Designing Tasks for the Communicative Classroom. Cambridge: Cambridge University Press.

Nurdyansyah \& Fahyuni, Eni Fariyatul, 2016. Inovasi Model Pembelajaran Sesuai Kurikulum 2013. Sidoarjo: Nizamia Learning Center

Utami, Indah Hari \& Hasanah, Uswatun. 2020. Kompetensi Profesional Guru dalam Penerapan Pembelajaran Tematik di SD Negeri Maguwoharjo 1 YOGYAKARTA. Fakultas Tarbiyah dan Ilmu Keguruan UIN Sunan Kalijaga Yogyakarta. Di akses di https://jurnal.arraniry.ac.id/index.php/Pionir/article/d ownload/6232/3809

Yaqin, L. N., \& Zainuddin, M. (2017). Male And Female Role In Conversation Of The Students At English Language Education Department Of Gunung Rinjani University: A Linguistic Feature Of Spoken Discourse Study. Journal IImiah Rinjani: Media Informasi IImiah Universitas Gunung Rinjani, 5(1), 137151.

Yulianto, Aris, 2016. Penerapan Model Pembelajaran Project Based Learning Berbasis Lesson Study Untuk Meningkatkan Keaktifan Belajar IPS Geografi Siswa Kelas VII A MTs Sunan Kalijogo Kota Malang. Seminar Nasional Hasil Penelitian, 2016. Malang: Universitas Negeri Malang. 